\title{
Preface to the 1994 Edition
}

I began writing this book in January 1986, and I fully anticipated its completion within six months. Although I knew much of the story, I discovered that I needed to learn more. Many new books and articles had to be perused, and not a few old works had to be reread. Moreover, ongoing civil conflict raised the question of what Ethiopia was. Several of the "liberation movements" argued against Ethiopia as a nation, defining it as an obsolete empire-state, a prison house of peoples. Though I was predisposed toward the Ethiopia I had studied since the late 1950s, I appreciated that within its frontiers were a variety of peoples.

The Tigray and the Amhara of highlands Eritrea, Tigray, Welo, Gonder, Shewa, and Gojam are the inheritors and avatars of Orthodox Christianity and its political traditions. They use plows to cultivate grains, and they also herd cattle, sheep, and goats. Their primary affiliation is to the Orthodox church, and they are loosely organized into parishes. Priests and itinerant holy men keep the banner of Christianity high and drill their auditors to believe in their moral and religious superiority. The clerics have kept alive the myth of a Christian empire whose origins go back to Axum and even to King Solomon's Israel. 
Within Ethiopia there are also large populations of Muslims: the Cushitic-speaking Afar, Saho, and Somali in the desert lowlands in the eastern parts of Eritrea, Tigray, Welo, and Harerge; and the Semiticspeaking Adari of Harer. Islam is also well represented in the large mercantile communities of Gonder, Addis Abeba, and other centers. Since the overthrow of Haile Sellassie in 1974, Islam has spread throughout Ethiopia, as evidenced by a large number of newly built mosques.

In the Gibe region, Harerge, and Arsi are millions of Cushiticspeaking Oromo Muslims; in Borena, hundreds of thousands of Oromo traditionalists; and in Welega, Welo, and southern Shewa, millions of Christian Oromo, many of whom speak Amharic as their mother tongue. As the country's majority and most widely dispersed people, the Oromo are present in at least twelve clusters in ten provinces. Over the last three centuries, most Oromo have transformed themselves into farmers, although they continue to revere animal keeping.

In Ethiopia's southern lacustrine regions live a variety of peoples, of whom the most important are the Semitic-speaking Gurage and the Cushitic-speaking Konso and Sidama. They are hoe agriculturists who cultivate ensete. The Gurage are mostly Muslim, but they number some Christians among them. The Sidama include Muslims, Christians, and traditionalists, whereas the Konso mostly follow a traditional African monotheism.

Besides the small Omotic-speaking family inhabiting a region adjacent to the Omo, an important population of Sudanic peoples dwell along Ethiopia's western border. Among them are the Koman, Kunama, Berta, and Annuak, who speak Nilo-Saharan tongues and live in largely segmented societies. Although these and other groups were essentially peripheral to the main strands of the history of the highlands Ethiopian state, recently scholars have studied their social history, to include them in the record. Not surprisingly, they were found to harbor grievances against the northern state builders, whose government they considered elitist and exploitative.

The government of Mengistu Haile Mariam (1974-1991) was also interested in Ethiopia's national composition, for reasons dictated by Marxist-Leninist theory and politics. It posed as its peoples' savior and envisioned their prosperity and happiness within the Socialist motherland that it was building for the so-called broad masses. As Mengistu's government grew increasingly authoritarian and intrusive, spokesmen for this or that nationality rose to the challenge and waged propaganda wars 
against the regime's politics. The assertions made by Ethiopians at home and abroad often were distorted by hyperbole, disaffecting a whole generation of Ethiopianists from the object of their scholarship. They left Ethiopian studies or became politicized for or against the warring factions.

As I watched the intellectual mayhem and continued my research, I came to realize that Ethiopia's history contained an analytical truth validating my decision to consider Ethiopia's wider geographic limits as my canvas: from time to time, the nation had disintegrated into component parts, but it had never disappeared as an idea and always reappeared in fact. The Axumite Empire may have faded after the seventh century, but the Zagwes followed in the eleventh century; and, of course, the succeeding Solomonic dynasty created a state that incorporated at least two-thirds of the country's present area. In the sixteenth century, that empire lost its will to rule after being ravaged by Muslim armies waging holy war, and it sharply contracted in the seventeenth century as the Oromo successfully invaded the devastated and depopulated highlands.

Even as the Solomonic monarchy weakened in the eighteenth century, the imperial tradition remained validated in Ethiopia's monasteries and parish churches. The northern peasantry was continually reminded of Ethiopia's earlier greatness and exhorted to work toward its renaissance. From 1896 to 1907, Menilek II (1889-1913) directed Ethiopia's return into southern and western regions abandoned in the seventeenth century. Modern firearms gave the emperor's soldiers a strategic advantage, but their morale was inspired by expectations of booty and the belief that they were regaining lands once part of the Christian state. By the end of the expansion in 1906, Ethiopia (without Eritrea) had reached its present size, comprising the highlands, the key river systems, and the state's central core, surrounded by a borderland buffer zone in low-lying, arid, or tropical zones.

From the Axumite period, public history in Ethiopia has moved from north to south, and the twentieth-century state developed along this well-trodden path. Menilek and his governors ruled Ethiopia's heterogeneous population indirectly, largely through accommodation and cooption. Haile Sellassie centralized the state and expanded Ethiopia's civil society as a counterweight to ethnic forces. He fostered unity through the development of a national army, a pan-Ethiopian economy, modern communications, and an official culture whose main feature was the use of the Amharic language in government and education. 
As Ethiopia's economy moved toward capitalism in the 1960s, considerable social unrest among the intelligentsia and in the provinces undermined the national consensus. Indeed, the Eritreans rebelled, claiming that they were a separate people largely because of their experiences under Italian and British colonial rule. Throughout the 1960s and 1970s, the authorities resorted to police or military repression to keep Ethiopia intact or enlisted clients to bolster its administration, as in the case of the Ogaden.

Haile Sellassie's government was overthrown in 1974 and replaced by an ideologically driven inclusivist state determined to extirpate any competing civil society or ethnic activity. Ruthless suppression of ideological adversaries fostered the growth of nationality movements and ongoing civil wars. The military government's tightly centralized authority imposed land tenure and supposedly "progressive" social policies that undermined the peasants' historic connection to the state and the land. Resettlement, villagization, mass political organizations, and the command economy conspired to alienate the people from their natural allegiances. The state's inability to compromise politically further encouraged the breakup of the larger nation.

Yet, if history is to be our guide, such a development will give way inevitably to renewed national unity as the logic of geography, economics, tradition, and political culture once again come to dominate politics. Some people may disagree with this hypothesis or other aspects of my book. I make no apologies but rather submit my synthesis as a challenge: prove me wrong, clarify my points, reveal where my work is insubstantial, and show where other and better analyses might have been offered. If this book stimulates scholarship and amplifies our knowledge of Ethiopian history, then it will have proved its worth beyond merely being a guide through a complex and difficult story. This achievement is my great hope.

This volume is the culmination of many years' work, and its faults are all mine. Blameless are those of my friends, colleagues, and students whose criticisms helped bring the book to completion: John Hinnant, Donald Crummey, James McCann, Guluma Gemeda, Daniel Kendie, Patrick Gilkes, Ezekiel Gebissa, Charles McClellan, Yakob Fisseha, William Hixon, David Robinson, Richard Greenfield, and Jay Spaulding. Once again, I offer a special appreciation to Susan Drabik, who survived life with me during the book's long gestation. To the National Humanities Center-truly the "southern part of heaven" - where the first part of the book was written and the final draft edited, I present my deep and 
enduring gratitude. I am a fan for life. To the Social Science Research Council, the American Philosophical Society, and to Michigan State University, I say keep up the good work of supporting research, reflection, and scholarship. Thank you very much for your confidence in me.

Harold Marcus

National Humanities Center, July 1992 
